\title{
NÃO LEVANDO OS CUSTOS DOS DIREITOS A SÉRIO: O DIREITO PRESTACIONAL À SAÚDE PELO SUPREMO TRIBUNAL FEDERAL
}

Not taking the costs of rights seriously: the right to health by the Brazilian Federal Supreme Court

${ }^{1}$ Universidade Federal do Pampa. Porto Alegre/RS, Brasil.

Correspondência: Hector Cury Soares. E-mail: hectorcury@gmail.com.

Recebido em: 12/12/2014. Revisado em: 05/05/2015. Aprovado em: 11/05/2015. 


\section{RESUMO}

O presente artigo apresenta o distanciamento entre os apontamentos doutrinários e as decisões do Supremo Tribunal Federal no tocante ao direito prestacional à saúde. Para tanto, são realizadas revisão bibliográfica e análise do conteúdo de decisões do STF em relação ao direito prestacional à saúde. De um lado, a doutrina constitucional define o custo dos direitos como um elemento a ser considerado na teoria dos direitos fundamentais; de outro, a jurisprudência do Supremo Tribunal Federal (STF) descarta-o como elemento relevante para a decisão que venha a adotar. $\mathrm{O}$ descompasso entre doutrina e jurisprudência implica o prejuízo de uma interpretação constitucionalmente adequada dos direitos sociais prestacionais.

\section{Palavras-Chave}

Custos dos Direitos; Direito Prestacional à Saúde; Supremo Tribunal Federal.

\section{ABSTRACT}

The current study presents the discrepancy between theoretical declarations and Brazilian Federal Supreme Court decisions regarding the constitutional right to health. Therefore, this study conducts a review and analysis of the literature and content on Supreme Court decisions regarding the constitutional right to health care. On the one hand, the constitution defines the cost of rights as a factor to be considered in the theorization of fundamental rights; on the other hand, the jurisprudence of the Brazilian Federal Supreme Court discards cost as a relevant element when deciding. The disconnection between doctrine and jurisprudence affects a constitutionally adequate interpretation on constitutionally given social rights.

\section{Keywords}

Brazilian Federal Supreme Court; Cost of Rights; Right to Health. 


\section{Introdução}

Um aspecto recorrente na questão ligada à justiciabilidade do direito prestacional à saúde é o custo. Percebemos que é voz comum, na doutrina e na jurisprudência brasileiras, a afirmação de que os direitos sociais fundamentais geram custos $^{1}$. Ou, mesmo, afirma-se que o deferimento judicial de prestações em saúde possibilita obliquamente a inefetividade de prestações previstas para a coletividade em função do comprometimento do orçamento ${ }^{2}$.

Por terem custos, os direitos refletem no orçamento público, visto que o Estado depende dele para prover o direito prestacional à saúde. Isso gera a necessidade de as despesas serem adequadas aos recursos disponíveis. O poder público não foge a esta regra para a efetivação dos direitos fundamentais sociais. Assim, prestações estatais demandam recursos.

Na Constituição Federal de 1988 (CF/88), o plano plurianual (PPA), a lei de diretrizes orçamentárias (LDO) e a lei orçamentária anual (LOA) são os meios utilizados pelo Estado para planejar sua ação; porém, é na LOA que há a aplicação concreta de recursos na efetivação de direitos. No artigo 165, parágrafo $8^{\circ}$, e no artigo $167^{3}$, há a disposição de que os recursos que o Estado prevê arrecadar e as despesas

\footnotetext{
${ }^{1}$ Aspectos jurisprudenciais e doutrinários que serão referenciados ao longo do capítulo.

${ }^{2}$ BARROSO, Luis Roberto. Da falta de efetividade à judicialização excessiva: direito à saúde, fornecimento gratuito de medicamentos e parâmetros para a atuação judicial. Disponível em: <http://www.Irbarroso.com. $\mathrm{br} / \mathrm{pt} /$ noticias/medicamentos.pdf>. Acesso em: 08 nov. 2008.

3“Art. $165, \S 8^{\circ}$. A lei orçamentária anual não conterá dispositivo estranho à previsão da receita e à fixação da despesa, não se incluindo na proibição a autorização para abertura de créditos suplementares e contratação de operações de crédito, ainda que por antecipação de receita, nos termos da lei". "Art. 167. São vedados: I - o início de programas ou projetos não incluídos na lei orçamentária anual; II - a realização de despesas ou a assunção de obrigações diretas que excedam os créditos orçamentários ou adicionais; III - a realização de operações de créditos que excedam o montante das despesas de capital, ressalvadas as autorizadas mediante créditos suplementares ou especiais com finalidade precisa, aprovados pelo Poder Legislativo por maioria absoluta; IV - a vinculação de receita de impostos a órgão, fundo ou despesa, ressalvadas a repartição do produto da arrecadação dos impostos a que se referem os arts. 158 e 159, a destinação de recursos para as ações e serviços públicos de saúde, para manutenção e desenvolvimento do ensino e para realização de atividades da administração tributária, como determinado, respectivamente, pelos arts. 198, $\S 2^{\circ}, 212$ e 37, XXII, e a prestação de garantias às operações de crédito por antecipação de receita, previstas no art. $165, \S 8^{\circ}$, bem como o disposto no $\S 4^{\circ}$ deste artigo; $V$ - a abertura de crédito suplementar ou especial sem prévia autorização legislativa e sem indicação dos recursos correspondentes; $\mathrm{VI}$ - a transposição, o remanejamento ou a transferência de recursos de uma categoria de programação para outra ou de um órgão para outro, sem prévia autorização legislativa; VII - a concessão ou utilização de créditos ilimitados; VIII - a utilização, sem autorização legislativa específica, de recursos dos orçamentos fiscal e da seguridade social para suprir necessidade ou cobrir déficit de empresas, fundações e fundos, inclusive dos mencionados no art. 165, $\S 5^{\circ}$; IX - a instituição de fundos de qualquer natureza, sem prévia autorização legislativa. $X$ - a transferência voluntária de recursos e a concessão de empréstimos, inclusive por antecipação de receita, pelos Governos Federal e Estaduais e suas instituições financeiras, para pagamento de despesas com pessoal ativo, inativo e pensionista, dos Estados, do Distrito Federal e dos Municípios. XI - a utilização dos recursos provenientes das contribuições sociais de que trata o art. 195, I, a, e II, para a realização de despesas distintas do pagamento de benefícios do regime geral de previdência social de que trata o art. 201. $\S 1^{\circ}$ - Nenhum investimento cuja execução ultrapasse um exercício financeiro poderá ser iniciado sem prévia inclusão no plano plurianual, ou sem lei que autorize a inclusão, sob pena de crime de responsabilidade. $\S 2^{\circ}$ - Os créditos especiais e extraordinários terão vigência no exercício financeiro em
} 
que estará autorizado a realizar devem constar no orçamento anual. Nesse sentido, o orçamento assegura o confronto entre os recursos possíveis e as despesas necessárias.

A aplicação de recursos tem, como consequência, a escolha de áreas, programas e projetos que sejam considerados prioritários na efetivação do direito prestacional à saúde; a escolha política adotada é corporificada com a LOA. No caso da saúde, a Constituição assegura uma estrutura financeira mínima à efetivação de seu direito, além da estrutura para a operacionalização das prestações (Sistema Único de Saúde - SUS).

Não há recursos disponíveis para todas as necessidades em termos de saúde pública, por isso são feitas escolhas políticas na alocação desses recursos - escolhas estas que não devem ser feitas arbitrariamente, mas a partir de parâmetros que as justifiquem constitucionalmente.

A despeito da admissibilidade dos custos dos direitos, percebe-se que há uma resistência no Supremo Tribunal Federal (STF) em admitir a plausibilidade desse argumento como forma direta na decisão. Dentro das decisões do STF, encontramos aquelas em que o custo do direito é refutado como argumento, e aquelas em que o custo do direito é ponderado, mas não é relevante para decisão.

Com base nisso, tentaremos compreender o porquê de tamanha resistência do STF, em grande parte de suas decisões, ao óbvio: os direitos geram custos que devem ser ponderados na decisão. Essa posição gera um descompasso entre a teoria dos direitos fundamentais e a hermenêutica constitucional, além do impacto orçamentário.

Para tanto, por meio do sítio do STF, realizamos uma pesquisa com base nos termos "políticas públicas" e "saúde", limitada aos anos de 2009 até 2014. A delimitação temporal é em função da realização, em 2009, da Audiência Pública n. $4^{4}$ do STF, a qual versou acerca da judicialização da saúde. A ideia era verificar se houve algum efeito na jurisprudência a partir da audiência. Importante salientar que nem todas as decisões encontradas foram citadas ao longo do trabalho, em função da repetição dos argumentos em muitas delas.

\footnotetext{
que forem autorizados, salvo se o ato de autorização for promulgado nos últimos quatro meses daquele exercício, caso em que, reabertos nos limites de seus saldos, serão incorporados ao orçamento do exercício financeiro subseqüente. $\S 3^{\circ}$ - A abertura de crédito extraordinário somente será admitida para atender a despesas imprevisíveis e urgentes, como as decorrentes de guerra, comoção interna ou calamidade pública, observado o disposto no art. $62 . \S 44^{\circ}$ É permitida a vinculação de receitas próprias geradas pelos impostos a que se referem os arts. 155 e 156, e dos recursos de que tratam os arts. 157, 158 e 159, l, a e b, e II, para a prestação de garantia ou contragarantia à União e para pagamento de débitos para com esta". BRASIL. Constituição da República Federativa do Brasil de 1988. Disponível em: <http://www.planalto.gov. br/ccivil_03/constituicao/ConstituicaoCompilado.htm>. Acesso em: 16 set. 2015.

${ }^{4}$ BRASIL. SUPREMO TRIBUNAL FEDERAL. Audiência Pública n. 4, 27, 28 e 29 de abril, e 4, 6 e 7 de maio de 2009. Disponivel em: <http://www.stf.jus.br/portal/cms/verTexto.asp?servico=processoAudienciaPublicaS aude>. Acesso em: 17 set. 2015.
} 


\section{Não levando os custos a sério}

A despeito do estatuto constitucional, as políticas públicas de saúde não necessariamente atendem aos indivíduos e a suas necessidades ou, por vezes, atendem-nos de forma ineficiente ou são omissas. Não raro, encontramos notícias nas mídias sociais que veiculam informações acerca da saúde e cobram do poder público uma resposta em termos de efetivação do direito prestacional à saúde. Para que haja a concretização desse direito, tem-se exigido um Poder Judiciário mais responsivo às demandas sociais ${ }^{5}$.

O Poder Judiciário como instituição e, especificamente, o STF e o Superior Tribunal Justiça (STJ) tornam-se os bastiões da defesa dos direitos contra a opressão majoritária dos outros poderes ${ }^{6}$. Diante disso, a expectativa é de conjugação entre a justiciabilidade do direito à saúde e o equilíbrio do orçamento público, assegurando autonomia suficiente aos poderes Legislativo e Executivo para a efetivação desse direito.

A implementação do direito prestacional à saúde passa pela análise de seus custos e dos recursos disponíveis, visando a atender à integralidade desse direito. A escolha realizada necessariamente terá reflexos orçamentários e, nesse sentido, a efetivação do direito prestacional à saúde depende das decisões orçamentárias ${ }^{7}$. A definição, por exemplo, dos medicamentos que serão disponibilizados ou dos tratamentos que serão providos pelo SUS passa pela previsão de recursos destinados para essas prestações. É com base nas previsões orçamentárias em relação a despesas e receitas que o Estado pode corporificar o direito prestacional à saúde por meio de políticas públicas de saúde. Salientamos a lição de Holmes e Sunstein: "A legal right exists, in reality, only when and if it has budgetary costs"s.

No Brasil, o tema ganha relevância se levarmos em conta a realização da Audiência Pública n. do STF, que tratou dos limites à intervenção do Judiciário. Além disso, há um extenso rol de decisões da suprema corte brasileira ${ }^{9}$. Ademais,

\footnotetext{
${ }^{5}$ CAMPANTE, Rubens Goyatá. Direitos sociais e justiça. In: AVRITZER, Leonardo (Orgs.). Dimensões políticas da justiça. Rio de Janeiro: Civilização Brasileira, 2013. p. 379.

${ }^{6}$ MENDES, Conrado Hübner. Constitutional courts and deliberative democracy. Oxford: Oxford, 2013. (versão em kindle). pos. 123.

${ }^{7}$ Para se ter ideia, em relação ao Orçamento de 2014, estima-se o montante de $\mathrm{R} \$ 2.467 .589 .444 .955,00$ (dois trilhões, quatrocentos e sessenta e sete bilhões, quinhentos e oitenta e nove milhões, quatrocentos e quarenta e quatro mil, novecentos e cinquenta e cinco reais). Deste, o orçamento fiscal representa $R \$$ 1.066.252.289.590,00 (um trilhão, sessenta e seis bilhões, duzentos e cinquenta e dois milhões, duzentos e oitenta e nove mil, quinhentos e noventa reais). BRASIL. Projeto de Lei Orçamentária Anual (exercício financeiro de 2014). Disponível em: <http://www.planejamento.gov.br/secretarias/upload/Arquivos/sof/ ploa2014/Texto_Projeto_lei_PLOA_2014.pdf>. Acesso em: 03 jan. 2014.

${ }^{8}$ HOLMES, Stephen; SUNSTEIN, Cass R. The cost of rights: why liberty depends on taxes. New York: Norton, 2000. p. 19. "Um direito legal existe, na realidade, apenas quando e se tiver custos orçamentários". (tradução do autor) ${ }^{9}$ A pesquisa jurisprudencial compreende o período entre 2009 e 2014 para analisar os efeitos da Audiência Pública n. 4 de 2009. A base de dados consultada foi site do STF. Os termos consultados foram "políticas e públicas e saúde". Foram pesquisadas decisões da presidência, decisões monocráticas e decisões colegiadas do STF.
} 
Cortes Constitucionais, como da Argentina e da Colômbia, também questionam seu próprio papel em face de um ativismo em prol dos direitos sociais. Além-mar, a Corte Constitucional Sul-Africana tem apresentado posições de vanguarda quando a questão são os limites da atuação do Poder Judiciário em relação aos direitos fundamentais sociais em sentido estrito, como saúde e moradia; recentemente, o Tribunal Constitucional Português decidiu acerca de um mínimo existencial em termos de promoção da seguridade social ${ }^{10}$.

Doutrinariamente, a questão da justiciabilidade dos direitos sociais no Brasil passa por significativo avanço ${ }^{11}$. Mormente quanto às questões ligadas aos custos dos direitos, a Universidade Estadual do Rio de Janeiro é a precursora em pesquisas que, cientificamente, demonstram a plausibilidade da ponderação desse elemento pelo Judiciário ${ }^{12}$.

Embora não haja tradução publicada em língua portuguesa, não são poucas as referências no Brasil à obra de Holmes e Sustein ${ }^{13}$, que aparece em muitos julgados e é considerada para tratar da evidência dos custos dos direitos. Em suma, a obra de demonstra que todos os direitos são positivos, no sentido de que todos eles, independentemente de serem direitos de liberdade ou direitos econômicos, sociais e culturais, geram custos ao Estado ${ }^{14}$. Os autores expõem as fragilidades dessa dicotomia ao dizer que quase todo direito tem um dever correlato, e os deveres somente são cumpridos quando há a possibilidade de o

${ }^{10}$ PORTUGAL. Tribunal Constitucional Português. Acórdão n. 509/2002. Disponível em: <http://www.tribunalconstitucional.pt/tc/acordaos/20020509.html>. Acesso em: 16 set. 2015.

${ }^{11}$ Amplamente: CANELA JUNIOR, Osvaldo. Controle judicial de políticas públicas. São Paulo: Saraiva, 2011. PENNA, Saulo Versiani. O controle e implementação processual de políticas públicas no Brasil. Belo Horizonte: Fórum, 2011. DIAS, Maria Tereza Fonseca; ESTEVES, Júlio César dos Santos; FORTINI, Cristiana (Orgs.). Políticas públicas: possibilidades e limites. Belo Horizonte: Fórum, 2008. GRINOVER, Ada Pellegrini; WATANABE, Kazuo (Coords.). O controle jurisdicional de políticas públicas. Rio de Janeiro: Forense, 2011. VALLE, Vanice Regina Lírio do. Políticas públicas, direitos fundamentais e controle judicial. Belo Horizonte: Fórum, 2009. BARROS, Marcus Aurélio de Freitas. Controle jurisdicional de políticas públicas: parâmetros objetivos e tutela coletiva. Porto Alegre: Sergio Antonio Fabris, 2008. MOREIRA NETO, Diogo de Figueiredo. Quatro paradigmas do direito administrativo pós-moderno: legitimidade; finalidade; eficiência; resultados. Belo Horizonte: Fórum, 2008. MOREIRA NETO, Diogo de Figueiredo. Poder, Direito e Estado: o direito administrativo em tempos de globalização. Belo Horizonte: Fórum, 2011. COUTO, Cláudio Gonçalves. Constituição, competição e políticas públicas. Lua Nova, São Paulo, n. 65, p. 95-135, 2005. Disponível em: <http://www.scielo.br/pdf/In/n65/a05n65.pdf>. http://dx.doi.org/10.1590/S0102-64452005000200005. FIGUEIREDO, Marcelo. O controle de políticas públicas pelo Poder Judiciário no Brasil: uma visão geral. Revista Interesse Público, v. 44, p. 27-66, jul./ago. 2007. Disponível em: <http://revistas.pucsp.br/index.php/red/article/viewFile/736/509>. Acesso em: 17 set. 2015.

${ }^{12}$ MAURICIO JUNIOR, Alceu. A revisão judicial das escolhas orçamentárias: a intervenção judicial em políticas públicas Belo Horizonte: Fórum, 2009. MENDONÇA, Eduardo Bastos Furtado. A constitucionalização das finanças públicas no Brasil: devido processo orçamentário e democracia. Rio de Janeiro: Renovar, 2008. TORRES, Ricardo Lobo. Tratado de direito tributário e financeiro (o orçamento na Constituição). Rio de Janeiro: Renovar, 2000. v. 5. AMARAL, Gustavo. Direito, escassez \& escolha: em busca de critérios jurídicos para lidar com a escassez de recursos e as decisões trágicas. Rio de Janeiro: Renovar, 2001.

${ }^{13}$ HOLMES, Stephen; SUNSTEIN, Cass R., op. cit.

${ }^{14}$ Id. Ibid. p. 35. 
poder público fazê-los serem cumpridos, havendo, para tanto, a necessidade do desembolso ${ }^{15}$ de recursos do Estado ${ }^{16}$.

Assim, para a manutenção de qualquer que seja a geração/dimensão de direitos, o Estado necessita arrecadar (em outras palavras, precisa de recursos) para assegurar o provimento dos direitos previstos na CF/88. Tal arrecadação é possível, de forma regular, principalmente pelo pagamento de tributos ${ }^{17}$.

No entanto, o custo do direito prestacional à saúde deve ser ponderado pelo Poder Judiciário como um dos aspectos a ser considerado na decisão. Ao ser corporificado pela LOA, é um dos elementos constitucionais necessários à efetivação desse direito. Indo um pouco além, podemos asseverar que o custo pode, em determinadas circunstâncias, ser um argumento forte à negativa de uma prestação, sem que, com isso, o Judiciário afronte à $\mathrm{CF} / 88^{18}$.

Desta maneira, o custo é um dos elementos na efetivação do direito prestacional à saúde, mas não o único. Ignorar esse elemento representa um impacto orçamentário e uma violação da $\mathrm{CF} / 88$.

Quando nos voltamos às decisões do STF, as quais têm servido de guia aos demais tribunais pelo Brasil, percebemos duas posições que merecem ser expostas:

\footnotetext{
${ }^{15} \mathrm{~A}$ tese de Holmes e Sunstein está correta se considerarmos que as liberdades públicas demandam prestações positivas que assegurem o seu exercício. Se examinarmos, no Brasil, a totalidade de recursos que são alocados ao Poder Judiciário, às polícias e ao custo das eleições periódicas, perceberemos o quão significativo é o custo dos direitos de liberdade, tanto quanto os direitos econômicos, sociais e culturais. Ver MAURICIO JUNIOR, Alceu. op. cit., p. 59.

${ }^{16}$ Id. Ibid., p. 38.

17 “Estado fiscal é um Estado que necessita para o suporte de suas atividades e para o suporte dos direitos aos quais deve promover e quando se trata de suporte é no sentido financeiro. Contudo, sem perder de vista, como afirma Nabais, que a razão desse mesmo Estado é a realização da pessoa humana, a realização da pessoa no respeito pela sua eminente dignidade humana. Embora o Estado fiscal tenha no dever fundamental (constitucional) de pagar tributos a fonte financeira necessária à sua manutenção, o tem sem poder perder de vista que esse mesmo Estado é um instrumento da realização da dignidade humana e que esse dever constitucional de pagar tributos assenta-se num primado de solidariedade, ou seja, de compartilhamento do custo da manutenção do Estado e, em última instância, da manutenção da dignidade da pessoa humana (ou de condições para essa conservação)". NABAIS, José Casalta. A face oculta dos direitos fundamentais: os deveres e os custos dos Direitos. In: NABAIS, José Casalta. Por uma liberdade com responsabilidade: estudos sobre direitos e deveres fundamentais. Coimbra: Coimbra Ed., 2007. p. 179. Id. O dever fundamental de pagar impostos: contributo para a compreensão constitucional do estado fiscal contemporâneo. Lisboa: Almedina, 1998. "Todos os direitos sociais fundamentais geram muito custo, o que faz o Estado é apenas distribuir somente aqueles recursos que, em forma de taxas e impostos, arrecada de outros indivíduos". (tradução do autor). ALEXY, Robert. Teoría de los derechos fundamentales. Madrid: Centro de Estudíos Politicos y Constitucionales, 2008. p. 453.

${ }^{18} \mathrm{CORTI}$, Horacio G. Derechos fundamentales y presupuesto público: una renovada relación en el marco del neoconstitucionalismo periférico. In: CONTI, José Mauricio; SCAFF, Fernando Facury (Coord.). Orçamentos públicos e direito financeiro. São Paulo: Ed. Revista dos Tribunais, 2011. p. 128-129. "Há uma total constitucionalização do ordenamento jurídico capaz de intrometer-se na legislação como na jurisprudência, no estilo doutrinal, na ação dos atores políticos, atribuindo uma força vinculante a todas as disposições jurídicas da Constituição; refletindo diretamente na capacidade financeira do Estado atender a todos os direitos prestacionais". GUASTINI, Riccardo. La constitucionalización del ordenamiento jurídico: el caso italiano. In: CARBONELL, Miguel. Neoconstitucionalismo(s). Madrid: Trotta, 2005. p. 49.
} 
(a) a posição maximalista sem ponderação de custos; e (b) a posição maximalista com ponderação de custos. Em ambas, como examinaremos, o elemento custo do direito apresenta-se apenas na esfera argumentativa, ainda longe de ser decisivo no deferimento ou indeferimento de uma demanda judicial.

\section{A posição maximalista sem ponderação de custos}

Esta pode ser considerada a posição tradicional na relação entre justiciabilidade do direito prestacional à saúde e a questão do custo. Ela se aproxima da ideia de que, quando a saúde e a vida estão em pauta, pode-se considerar qualquer referência ao custo como sendo repugnante ou até mesmo imoral. No entanto, a relevância do custo da saúde pública torna essa posição insustentável ${ }^{19}$.

No Brasil, é posta como verdadeira a assertiva - jurisprudencial - de que o fornecimento de medicamento (direito à saúde) não pode ser contrastado com questões menores, tais como o orçamento ${ }^{20}$. Nesse sentido, desperta atenção a Arguição de Descumprimento de Preceito Fundamental n. 45, de relatoria do ministro Celso de Mello - decisão amplamente divulgada e que é lugar comum em termos de aplicabilidade/exigibilidade de direitos sociais prestacionais:

A eficácia dos Direitos Fundamentais Sociais a prestações materiais depende, naturalmente, dos recursos públicos disponíveis; normalmente, há uma delegação constitucional para o legislador concretizar o conteúdo desses direitos. Muitos autores entendem que seria ilegítima a conformação desse conteúdo pelo Poder Judiciário, por atentar contra o princípio da Separação dos Poderes [...]. Muitos autores e juízes não aceitam, até hoje, uma obrigação do Estado de prover diretamente uma prestação a cada pessoa necessitada de alguma atividade de atendimento médico, ensino, de moradia ou alimentação. Nem a doutrina nem a jurisprudência têm percebido o alcance das normas constitucionais programáticas sobre direitos sociais, nem lhes dado aplicação adequada como princípios-condição da justiça social. A negação de qualquer tipo de obrigação a ser cumprida na base dos Direitos Fundamentais Sociais tem como consequência a renúncia de reconhecê-los como verdadeiros direitos. [...] Em geral, está crescendo o grupo daqueles que consideram os princípios constitucionais e as normas sobre direitos sociais como fonte de direitos e obrigações e admitem a intervenção do Judiciário em caso de omissões inconstitucionais ${ }^{21}$.

${ }^{19}$ AMARAL, Gustavo. Direito, escassez \& escolha: em busca de critérios jurídicos para lidar com a escassez de recursos e as decisões trágicas, cit., p. 136.

${ }^{20}$ AMARAL, Gustavo; MELO, Daniele. Há direitos acima dos orçamentos? In: SARLET, Ingo; TIMM, Luciano Benetti (Coords.). Direitos fundamentais: orçamento e "reserva do possível". Porto Alegre: Livr. do Advogado, 2013. p. 79.

${ }^{21}$ BRASIL. Supremo Tribunal Federal. Arguição de Descumprimento de Preceito Fundamental n. 45/DF. Rel. Min. Celso de Mello. Disponível em: <http://www.stf.jus.br/portal/jurisprudencia/visualizarEmenta.asp?s 1=000072044\&base=baseMonocraticas $>$. Acesso em: 06 dez. 2013. 
O relator Celso de Mello coloca de lado o custo dos direitos prestacionais em prol de sua aplicabilidade imediata, voltada a assegurar o mínimo em termos de prestações. Contudo, não fica claro, ao ignorar em sua arguição os aspectos orçamentários, quais elementos devem ser utilizados para determinar o mínimo.

Encontramos decisões do $\mathrm{STF}^{22}$ que reconhecem a aplicabilidade imediata do direito social a prestações em matéria de saúde como forma de assegurar um mínimo existencial quando houver omissão do Poder Legislativo na densificação desse direito ${ }^{23}$. Nessa perspectiva, a omissão de uma autoridade em cumprir seus deveres - isto é, tomar as medidas necessárias para a realização do direito à saúde - viola o princípio da dignidade da pessoa humana e vulnera o direito à saúde, bem como a integridade física, moral e psíquica da pessoa ${ }^{24}$.

Em grande parte, tais decisões do STF baseiam-se em posições adotadas pelo ministro Celso de Mello, na quais ele faz uma forte digressão na literatura dos direitos fundamentais, mormente abordando a temática da aplicabilidade imediata, inclusive com passagens acerca da obra de Holmes e Sunstein. Contudo, a referência é apenas para a construção do voto, pois não há uma ponderação dos custos e sua posição é maximalista.

Para as decisões inspiradas nos votos do ministro Celso de Mello, na prática, o princípio da dignidade da pessoa humana assume caráter totêmico e insuperável por quaisquer argumentos que porventura possam ser adotados no sentido de realizar uma ponderação.

Nessa perspectiva, há a Suspensão de Segurança n. 4304, em que o ministro Cezar Peluso mantém o fornecimento do medicamento Solaris e aduz que o custo por si só não é suficiente para o indeferimento. Neste caso, o medicamento tinha o custo de R\$1,8 milhão por ano e não continha registro na Agência Nacional de Vigilância Sanitária (Anvisa) ${ }^{25}$. O elemento custo é base para pensarmos uma teoria geral dos direitos fundamentais; não se trata de sua suficiência ou não, e há evidências de ordem teórica e normativa que nos insta a considerá-lo.

\footnotetext{
${ }^{22}$ BRASIL. Supremo Tribunal Federal. Agravo Regimental no Recurso Extraordinário n. 271286/ RS. Rel. Min. Celso de Mello. Disponível em: http://redir.stf.jus.br/paginadorpub/paginador. jsp?docTP=AC\&docID=335538>. Acesso em: 17 set. 2015. BRASIL. Supremo Tribunal Federal. Recurso Extraordinário n. 232335/RS. Rel. Min. Celso de Mello. Disponível em: <http://www.stf.jus.br/portal/jurisprudencia/listarJurisprudencia.asp?s1=\%28RE\%24\%2ESCLA\%2E+E+232335\%2ENUME\%2E\%29+NAO +S\%2EPRES\%2E\&base=baseMonocraticas\&url=http://tinyurl.com/bba4e8h>. Acesso em: 17 set. 2015.

${ }^{23} \mathrm{Da}$ mesma forma é reconhecido na jurisprudência constitucional colombiana. ARANGO, Rodolfo. El derecho a la salud en la jurisprudencia constitucional colombiana. Revista da Defensoria Pública do Estado de São Paulo, ano 1, n. 1, p. 96, jul./dez. 2008.

${ }^{24}$ ARANGO, Rodolfo. El concepto de derechos sociales fundamentales. Bogotá: Legis, 2012. p. 97.

${ }^{25}$ BRASIL. Supremo Tribunal Federal. Suspensão de Segurança n. 4304. Min. Cezar Peluso. Disponível em: <http://www.stf.jus.br/portal/jurisprudencia/listarJurisprudencia.asp?s1=\%28SS\%24\%2ESCLA\%2E+E+ 4304\%2ENUME\%2E\%29+E+S\%2EPRES\%2E\&base=basePresidencia\&url=http://tinyurl.com/c2wnzgo>. Acesso em: 17 set. 2015.
} 
Importante salientar que os entes federativos, no caso da demanda por medicamento, tratamento ou melhoria no SUS, geralmente, alegam em sua defesa que o deferimento traria um custo alto e afetaria sua ordem econômico-financeira. Ainda assim, esse argumento é menosprezado ou simplesmente não é analisado na decisão pelo STF. Isso porque, para o STF, o direito à vida e à dignidade de vida do paciente sobrepõe-se a argumentos de outras espécies, como ocorre na Suspensão de Tutela Antecipada n. $283^{26}$.

Da mesma forma, em relação ao fornecimento de alimento especial à criança carente, no Recurso Extraordinário n. 71324127, a relatora, ministra Carmem Lúcia, diz existir uma primazia do direito à vida e à dignidade da pessoa humana. Independentemente do custo, o Judiciário apenas assegura - ao deferir o pleito - direitos e garantias fundamentais do cidadão, que são pressupostos constitucionalmente. A mesma ministra, na relatoria do Recurso Extraordinário n. 665764 - em que a demanda era pela realização de exames cujo repasse de recursos não fora realizado em virtude do atingimento do teto orçamentário -, ignora a questão orçamentária ao dizer que "[n]ão há ofensa ao princípio da separação dos poderes (artigo 20, $\mathrm{CF} / 88$ ) ou em intervenção do Judiciário no mérito administrativo (oportunidade e conveniência) [...]"28. Alega que o Judiciário apenas exige o cumprimento de políticas estabelecidas constitucionalmente.

Notamos que o argumento relativo ao custo do direito prestacional à saúde é desconsiderado nesses julgamentos. O direito à saúde, nesse sentido, apresenta-se como um direito subjetivo definitivo vinculante ${ }^{29}$ em duas posições: a de ignorar o argumento relativo aos custos e a de refutar sua análise. Contudo, em ambos os casos, não é apresentada uma fundamentação clara de por quê. Nas palavras de Lopes, "a impressão que fica é a de que os tribunais concedem, sob a linguagem do

\footnotetext{
${ }^{26}$ BRASIL. Supremo Tribunal Federal. Suspensão de Tutela Antecipada n. 283. Min. Gilmar Mendes. Disponivel em: <http://www.stf.jus.br/portal/jurisprudencia/listarJurisprudencia.asp?s1=\%28STA\%24\%2ES CLA\%2E+E+283\%2ENUME\%2E\%29+E+S\%2EPRES\%2E\&base=basePresidencia\&url=http://tinyurl.com/ crpltd8>. Acesso em: 17 set. 2015. Comportamento reiterados em outros julgamentos como: BRASIL. Supremo Tribunal Federal. Suspensão de Segurança n. 4045. Min. Gilmar Mendes. Disponível em: <http:// www.stf.jus.br/portal/jurisprudencia/listarJurisprudencia.asp?s1=\%28SS $\% 24 \% 2 \mathrm{ESCLA} \% 2 \mathrm{E}+\mathrm{E}+4045 \% 2$ ENUME\%2E\%29+E+S\%2EPRES\%2E\&base=basePresidencia\&url=http://tinyurl.com/aw6lw2w>. Acesso em: 17 set. 2015. BRASIL. Supremo Tribunal Federal. Suspensão de Segurança n. 3852. Min. Gilmar Mendes. Disponível em: <http://www.stf.jus.br/portal/jurisprudencia/listarJurisprudencia.asp?s1=\%28S S\%24\%2ESCLA\%2E+E+3852\%2ENUME\%2E\%29+E+S\%2EPRES\%2E\&base=basePresidencia\&url=http:// tinyurl.com/ccz29jn>. Acesso em: 17 set. 2015.

${ }^{27}$ BRASIL. Supremo Tribunal Federal. Recurso Extraordinário n. 713241. Rel. Min. Carmen Lúcia. Disponível em: <http://www.stf.jus.br/portal/jurisprudencia/listarJurisprudencia.asp?s1=\%28RE\%24\%2ESCLA\%2E $+\mathrm{E}+713241 \% 2 \mathrm{ENUME} \% 2 \mathrm{E} \% 29+\mathrm{NAO}+\mathrm{S} \% 2 \mathrm{EPRES} \% 2 \mathrm{E} \&$ base=baseMonocraticas\&url=http://tinyurl.com/ pcx2ttj>. Acesso em: 17 set. 2015.

${ }^{28}$ BRASIL. Supremo Tribunal Federal. Recurso Extraordinário n. 665764. Rel. Min. Carmen Lúcia. Disponível em: <http://www.stf.jus.br/portal/jurisprudencia/listarJurisprudencia.asp?s1=\%28RE\%24\%2ESCLA\%2E+ $\mathrm{E}+665764 \% 2 \mathrm{ENUME} \% 2 \mathrm{E} \% 29+\mathrm{OU}+\% 28 \mathrm{RE} \% 2 \mathrm{EACMS} \% 2 \mathrm{E}+\mathrm{ADJ} 2+665764 \% 2 \mathrm{EACMS} \% 2 \mathrm{E} \% 29$ \&base=base Acordaos\&url=http://tinyurl.com/cdjr8I3>. Acesso em: 17 set. 2015.

${ }^{29}$ ALEXY, Robert. op. cit., p. 445 e p. 455.
} 
direito, aquilo que, na verdade, creem ser devido como as boas e velhas "obras de misericórdia' da tradição cristã" ${ }^{30}$.

A posição maximalista sem ponderação de custos sustenta-se na ideia de que, na esfera argumentativa, o peso do princípio da dignidade pessoa humana é absoluto em relação a quaisquer outros argumentos - ainda que estes também possam ter relevância constitucional. Diante da cobrança midiática, o STF dá a resposta conveniente a tais interesses por meio dessa posição, deixando de lado seu papel de guarda da Constituição de 1988. Uma simplificação que, em termos práticos, cria duas portas de ingresso ao SUS: buscar a tutela jurisdicional ou enfrentar as filas para retirar fichas nas unidades de saúde.

Diante do exposto, é possível concluirmos que: (a) há uma posição geral do STF tendente a deferir todos os pedidos no campo do direito prestacional à saúde; e (b) essa posição - aqui chamada de maximalista sem ponderação de custos ignora ou exclui a possibilidade de ponderar os custos como um argumento forte para a decisão.

\section{A posição maximalista com ponderação de custos}

Se, de um lado, há a posição maximalista sem ponderação de custos, de outro lado há a posição no STF que considera e pondera a existência do custo do direito prestacional à saúde. Essa posição irá, inclusive, salientar a importância das limitações orçamentárias como um elemento a ser considerado; entretanto, o custo do direito, nessas decisões, é um argumento fraco, sobrepondo-se à dicção irrestrita dos artigos $6^{\circ 31}$ e 196 da CF/88.

Na prática, essa posição revelou um avanço, pois trouxe a discussão dos custos dos direitos como um elemento relevante. Ainda que seja maximalista, representa um diferencial, por não mais colocar o princípio da dignidade da pessoa humana como um direito a priori. Em nosso entendimento, essa posição é fruto de paulatina maturidade revelada pelos debates apresentados na Audiência Pública n. 4 de 2009. Sem dúvida, a abertura do STF como um espaço de debate amplo de uma grande questão pública, amadurece os votos que passam a considerar os custos como um elemento a ser ponderado.

\footnotetext{
${ }^{30}$ LOPES, José Reinaldo de Lima. Os Tribunais e os direitos sociais no Brasil - saúde e educação: um estudo de caso revisitado. In: LOPES, José Reinaldo de Lima. Direitos sociais: teoria e prática. São Paulo: Método, 2006. p. 261.

31 “Art. $6^{\circ}$. São direitos sociais a educação, a saúde, a alimentação, o trabalho, a moradia, o transporte, o lazer, a segurança, a previdência social, a proteção à maternidade e à infância, a assistência aos desamparados, na forma desta Constituição. (Redação dada pela Emenda Constitucional n 90, de 2015)". "Art. 196. A saúde é direito de todos e dever do Estado, garantido mediante políticas sociais e econômicas que visem à redução do risco de doença e de outros agravos e ao acesso universal e igualitário às ações e serviços para sua promoção, proteção e recuperação". BRASIL. Constituição da República Federativa do Brasil de 1988, cit.
} 
Exemplo disso passou a ser a posição adotada pelo ministro Gilmar Ferreira Mendes, que, em votos de sua lavra após a Audiência Pública n. 4, passou a estabelecer critérios objetivos para o deferimento ou não. Critérios que passaram, desde então, a ser reproduzidos em decisões que versassem acerca do direito prestacional à saúde e do fornecimento de medicamentos/tratamento.

Nesse sentido, na Suspensão de Tutela Antecipada n. 316, o então presidente, ministro Gilmar Mendes pondera que o Estado está desobrigado a fornecer medicamentos/tratamentos:

a) cujos efeitos, senão idênticos, mas parecidos, possam ser obtidos com os remédios oferecidos gratuitamente; b) que não geram efeitos benéficos comprovados pela ciência, vale dizer, medicamentos ainda não aprovados pela Anvisa, ou que são inadequados para o caso do paciente postulante; c) cujos custos possam ser reduzidos mediante o fornecimento de medicamentos mais baratos, com os mesmos efeitos; d) experimentais; e) cujos custos sejam desproporcionais aos benefícios que promove; f) para fins puramente estéticos; g) a pacientes que não tenham se submetido aos tratamentos previstos pelo SUS e que têm indicação médica para o caso ${ }^{32}$. (destaques do autor)

Importante salientar que, no caso citado, o pedido de suspensão foi deferido em favor da União. Contudo, o que é consignado na decisão foi resultado, principalmente, da generalidade dos beneficiários, tendo em vista ser fruto de ação civil pública a fim de garantir o acesso aos medicamentos Plavix $75 \mathrm{~g}$ (Clopidogrel), Diltizem (Cardizem) e Sinvascor $40 \mathrm{~g}$ (Sinvatastina). Como podemos perceber, o argumento forte está relacionado às questões processuais; apesar de ponderado, $\mathrm{o}$ custo é desconsiderado na decisão.

Outra sorte de argumento, até mais aprofundado, aparece no Recurso Extraordinário n. 642536, julgado pela Primeira Turma e no qual o relator, ministro Luiz Fux, traz à tona a questão ligada ao custo do direito prestacional à saúde. $\mathrm{O}$ custo aparece como forma de justificar a intervenção. Isso porque a teoria dos custos dos direitos levaria a doutrina a defender o caráter programático dos direitos sociais, conforme exarado no voto:

As divergências doutrinárias quanto ao efetivo âmbito de proteção da norma constitucional do direito à saúde decorrem, especialmente, da natureza prestacional desse direito e da necessidade de compatibilização do que se convencionou denominar "mínimo existencial"

\footnotetext{
${ }^{32}$ BRASIL. Supremo Tribunal Federal. Suspensão de Tutela Antecipada n. 316. Min. Gilmar Mendes. Disponivel em: <http://www.stf.jus.br/portal/jurisprudencia/listarJurisprudencia.asp?s1=\%28STA\%24\%2ES CLA\%2E+E+316\%2ENUME\%2E\%29+E+S\%2EPRES\%2E\&base=basePresidencia\&url=http://tinyurl.com/ d5d4zvj>. Acesso em: 17 set. 2015.
} 
e "reserva do possível" (Vorbehalt des Möglichen). Ressalto, nessa perspectiva, as contribuições de Stephen Holmes e Cass Sunstein para o reconhecimento de que todas as dimensões dos direitos fundamentais têm custos públicos, dando significativo relevo ao tema da "reserva do possível", especialmente ao evidenciar a "escassez dos recursos" e a necessidade de se fazerem escolhas alocativas, concluindo, a partir das perspectivas das finanças públicas, que "levar a sério os direitos significa levar a sério a escassez" (HOLMES, Stephen; SUNSTEIN, Cass. The Cost of Rights: Why Liberty Depends on Taxes. W. W. Norton \& Company: Nova Iorque, 1999). A dependência de recursos econômicos para a efetivação dos direitos de caráter social leva parte da doutrina a defender que as normas que consagram tais direitos assumem a feição de normas programáticas, dependentes, portanto, da formulação de políticas públicas para se tornarem exigíveis. Nesse sentido, também se defende que a intervenção do Poder Judiciário, ante a omissão estatal quanto à construção satisfatória dessas políticas, violaria o princípio da separação dos poderes e o princípio da reserva do financeiramente possível ${ }^{33}$.

Todavia, não nos parece adequada a relação exposta pelo citado ministro. A nosso ver, a teoria dos custos dos direitos como elemento dos direitos sociais prestacionais não deve servir de salvaguarda para a justificação da não intervenção por alguma espécie de caráter programático das normas constitucionais e, tampouco, para alguma violação do princípio de separação dos poderes.

Em outros dois recursos extraordinários ${ }^{34}$, o relator, ministro Ricardo Lewandowski, mantém o fornecimento de medicamento alegando que, no caso do elemento

\footnotetext{
${ }^{33}$ BRASIL. Supremo Tribunal Federal. Recurso Extraordinário n. 642536. Rel. Min. Luiz Fux. Disponível em: <http://www.stf.jus.br/portal/jurisprudencia/listarJurisprudencia.asp?s1=\%28RE\%24\%2ESCLA\%2E+E +642536\%2ENUME\%2E\%29+NAO+S\%2EPRES\%2E\&base=baseMonocraticas\&url=http://tinyurl.com/ ayt3qnb>. Acesso em: 17 set. 2015. Há uma decisão, de lavra do ministro Luiz Fux, quando atuava no STJ, na qual defere exatamente a compra do medicamento Interferon Peguilado (que não consta no protocolo do SUS) para um caso de hepatite C, baseado em uma posição "maximalista" dos artigos $6^{\circ}$ e 196 da CF/88, ao dizer que o Estado deve "propiciar aos necessitados não 'qualquer tratamento', mas o tratamento mais adequado e eficaz, capaz de ofertar ao enfermo maior dignidade e menor sofrimento". Em voto-vista, vencido, o ministro Teori Zavascki aduz que o direito individual à saúde não é incondicionado, baseado na ideia de suportabilidade de um mínimo existencial, do qual o Poder Judiciário deve ser fiador. A concretização do direito prestacional à saúde deve adequar-se "às condições de atendimento do dever estatal, de acordo com a capacidade orçamentária e as demais prioridades de gastos”. BRASIL. Superior Tribunal de Justiça. Recurso em Mandado de Segurança n. 24197/PR. Rel. Min. Luiz Fux. Disponível em: <http://www.stf.jus.br/portal/ jurisprudencia/listarJurisprudencia.asp?s1=\%28MS\%24\%2ESCLA\%2E+E+24197\%2ENUME\%2E\%29+NAO+ S\%2EPRES\%2E\&base=baseMonocraticas\&url=http://tinyurl.com/aykbbd9>. Acesso em: 17 set. 2015.

${ }^{34}$ BRASIL. Supremo Tribunal Federal. Recurso Extraordinário n. 628293. Rel. Min. Ricardo Lewandowski. Disponivel em: <http://www.stf.jus.br/portal/jurisprudencia/listarJurisprudencia.asp?s1=\%28RE\%24\%2 ESCLA\%2E+E+628293\%2ENUME\%2E\%29+NAO+S\%2EPRES\%2E\&base=baseMonocraticas\&url=http:// tinyurl.com/I3czv5a>. Acesso em: 17 set. 2015. BRASIL. Supremo Tribunal Federal. Recurso Extraordinário n. 628345. Rel. Min. Ricardo Lewandowski. Disponível em: <http://www.stf.jus.br/portal/jurisprudencia/ listarJurisprudencia.asp?s1=\%28RE\%24\%2ESCLA\%2E+E+628345\%2ENUME\%2E\%29+NAO+S\%2EPRES \%2E\&base=baseMonocraticas\&url=http://tinyurl.com/pm43kpl>. Acesso em: 17 set. 2015.
} 
custo, a reserva do possível é limitada pelo atendimento ao mínimo existencial. Assim, o direito prestacional à saúde, em virtude de seu caráter fundamental e de cunho positivo, não pode ser descumprido pelo Estado. Em ambos os julgados citados, o voto do relator não verifica, realmente, as limitações orçamentárias expostas.

No mesmo sentido, em voto no Agravo Regimental na Suspensão de Tutela Antecipada n. 175, o ministro Celso de Mello aduz que

\begin{abstract}
não se ignora que a realização dos direitos sociais depende de vínculo financeiro e gradualidade, deve-se exigir o razoável do Estado [...] não pode o Poder Público criar obstáculo artificial que inviabilize a efetividade dos direitos prestacionais [...] a reserva do possível não pode ser invocada pelo Estado para eximir-se do cumprimento de suas obrigações constitucionais, notadamente quando, dessa conduta governamental negativa, puder resultar nulificação ou, até mesmo, aniquilação de direitos constitucionais impregnados de um sentido essencial de fundamentalidade ${ }^{35}$. (destaques do autor)
\end{abstract}

Os custos são apresentados como elemento importante. Em nossa pesquisa, que abrange os anos de 2009 a 2014, o custo do direito é preponderante como elemento a ser considerado em apenas uma decisão (decisão de presidência) ${ }^{36}$.

\footnotetext{
${ }^{35}$ BRASIL. Supremo Tribunal Federal. Agravo Regimental na Suspensão de Tutela Antecipada n. 175. Rel. Min. Gilmar Mendes. Pleno. Disponivel em: <http://www.stf.jus.br/portal/processo/verProcessoAndamento.asp?incidente=2570693 >. Acesso em: 17 set. 2015. Entendimento reproduzido nas seguintes decisões: BRASIL. Supremo Tribunal Federal. Agravo Regimental na Suspensão de Liminar n. 47. Rel. Min. Gilmar Mendes. Pleno. Disponível em: <http://www.stf.jus.br/portal/processo/verProcessoAndamento. asp?incidente $=2252830>$. Acesso em: 17 set. 2015. BRASIL. Supremo Tribunal Federal. Agravo Regimental no Recurso Extraordinário n. 581352. Rel. Min. Celso de Mello. Segunda Turma. Disponível em: <http://www. stf.jus.br/portal/processo/verProcessoAndamento.asp?incidente=2603764>. Acesso em: 17 set. 2015.

${ }^{36}$ Exceção que deve ser feita à decisão do ministro Joaquim Barbosa, na Suspensão de Tutela Antecipada n. 748, ao pedido de "Estimulação craniana transmagnética" em que diz: “a) as provas trazidas aos autos pelo autor da ação ordinária não confirmaram o caráter urgente do procedimento requerido, bem como não evidenciaram a busca prévia por alternativas oferecidas no âmbito do SUS. Colho da decisão que indeferiu o pedido de tutela antecipada; b) Em momento algum afirma a necessidade insofismável da utilização deste tratamento específico e a inexistência de outro tratamento apto a preservar a saúde do demandante; c) seria por demais injusto com os demais cidadãos necessitados relativizar o princípio da reserva do possível para conceder um tratamento alternativo de $\mathrm{R} \$ 68.000,00$ (sessenta e oito mil reais), notadamente porque este valor causaria abalos injustificáveis às finanças municipais, o que certamente refletiria no fornecimento de tratamentos específicos a outros administrados mais necessitados; d) em se tratando de tratamento a ser custeado pelos cofres públicos, este deve ser feito nos moldes previstos pelo Sistema Único de Saúde, porquanto não há nos autos a prova inequívoca a atestar a verossimilhanças das alegações de que o medicamento requerido privilegia a saúde (e não a "melhor saúde"), imprescindível à vida do paciente. e) Não é razoável subentender-se que todo e qualquer tratamento/recomendação médica deve ser atribuído ao Estado, sendo necessário que o Poder Judiciário apenas intervenha nas políticas públicas de saúde quando estas inexistirem ou flagrantemente se apresentarem insuficientes ao atendimento das necessidades da população, em caráter geral, e, excepcionalmente, por uma questão de ponderação entre princípios, quando ocorrer o iminente risco de vida ou de dano irreversível à saúde do paciente." BRASIL. Supremo Tribunal Federal. Suspensão de Tutela Antecipada n. ${ }^{\circ} 748$. Min. Joaquim Barbosa. Disponível em: <http://www.stf.jus. $\mathrm{br} /$ portal/jurisprudencia/listarJurisprudencia.asp?s1=\%28STA\%24\%2ESCLA $\% 2 \mathrm{E}+\mathrm{E}+748 \% 2 \mathrm{ENUME} \% 2 \mathrm{E} \% 2$ 9+E+S\%2EPRES\%2E\&base=basePresidencia\&url=http://tinyurl.com/kw4fgmv>. Acesso em: 17 set. 2015.
} 
Isso não significa consignar que os custos dos direitos sociais podem se tornar uma escusa liberalizante da realização dos direitos fundamentais sociais ${ }^{37}$, tampouco pode ter tamanha força, que razões individuais não possam (direito subjetivo) superar razões financeiras, encaminhando-nos para uma concepção de Estado de custos mínimos ${ }^{38}$. A CF/88 previu os recursos para o custeio do direito prestacional à saúde, estabelecendo uma específica garantia financeira para sua concretização ${ }^{39}$. Para tanto, assegurou um orçamento mínimo à saúde no artigo 198, parágrafos $1^{\circ}, 2^{\circ}$ e $3^{\circ 40}$, definindo as fontes orçamentárias para o custeio dos gastos com o SUS ${ }^{41}$. Assim, levar o custo do direito prestacional à saúde a sério é, em última instância, levar a Constituição a sério.

Nesse sentido, percebe-se que há um avanço, por parte de alguns ministros do STF, proporcionado pelos resultados da Audiência Pública n. 4/2009. Aparentemente, com base na posição do ministro Gilmar Mendes, houve uma maior criterização na concessão ou não. Dentro dessa posição, o custo do direito passou a ser sopesado na decisão.

37 “O discurso neoliberal postula o rompimento da concepção de Estado de bem-estar". GRAU, Eros Roberto. O discurso neoliberal e a teoria da regulação. In: CAMARGO, Ricardo Antônio Lucas (Coord.). Desenvolvimento econômico e intervenção do Estado na Ordem Constitucional: estudos jurídicos em homenagem ao Professor Washington Peluso Albino de Souza. Porto Alegre: Sergio Antonio Fabris, 1995. p. 62. HAYEK, Friedrich. O caminho para a servidão. Lisboa: Edições 70, 2009. p. 134. FRIEDMAN, Milton. Capitalism and freedom. Chicago: Chicago Press, 2002. p. 179-181. Tampouco as razões aqui expostas advogam por um Estado de custos mínimos. Não desconsiderar o argumento da escassez de recursos não representa necessariamente uma vinculação a políticas de corte de gasto público "antes de qualquer expediente voltado a aumentar diretamente a receita". TORRES, Ricardo Lobo. As relações entre receita e despesa na Constituição. In: COUTINHO, Jacinto Nelson de Miranda; MORAIS, José Luis Bolzan; STRECK, Lenio Luiz. Estudos constitucionais. Rio de Janeiro: Renovar, 2007. p. 361. GRAU, Eros Roberto. A Ordem Econômica na Constituição de 1988. São Paulo: Malheiros Ed., 2007. p. 44.

${ }^{38}$ No caso dos remédios para portadores do vírus HIV, o STF encampou a seguinte tese: "a falta de previsão orçamentária não deve preocupar ao juiz que Ihe incumbe a administração da justiça, mas, apenas ao administrador que deve atender equilibradamente as necessidades dos súditos, principalmente os mais necessitados e os doentes". BRASIL. Supremo Tribunal Federal. Agravo no Recurso Extraordinário n. 273834. Rel. Min. Celso de Mello. Disponivel em: <http://www.stf.jus.br/portal/jurisprudencia/listarJurisprudencia. asp?s1=\%28RE\%24\%2ESCLA\%2E+E+273834\%2ENUME\%2E\%29+NAO+S\%2EPRES\%2E\&base=baseMo nocraticas\&url=http://tinyurl.com/aqjqa4c>. Acesso em: 17 set. 2015. ALEXY, Robert. op. cit., p. 466.

${ }^{39}$ NUNES, António José Avelãs; SCAFF, Fernando Facury. Os tribunais e o direito à saúde. Porto Alegre: Livraria do Advogado, 2011. p. 83.

40 “Art. 198, § $1^{\circ}$. O sistema único de saúde será financiado, nos termos do art. 195, com recursos do orçamento da seguridade social, da União, dos Estados, do Distrito Federal e dos Municípios, além de outras fontes; § $2^{\circ}$ A União, os Estados, o Distrito Federal e os Municípios aplicarão, anualmente, em ações e serviços públicos de saúde recursos mínimos derivados da aplicação de percentuais calculados sobre: I - no caso da União, na forma definida nos termos da lei complementar prevista no $\S 3^{\circ}$; II - no caso dos Estados e do Distrito Federal, o produto da arrecadação dos impostos a que se refere o art. 155 e dos recursos de que tratam os arts. 157 e 159, inciso I, alínea a, e inciso II, deduzidas as parcelas que forem transferidas aos respectivos Municípios; III - no caso dos Municípios e do Distrito Federal, o produto da arrecadação dos impostos a que se refere o art. 156 e dos recursos de que tratam os arts. 158 e 159, inciso I, alínea b e $\S 3^{\circ}$; $\S 3^{\circ}$ Lei complementar, que será reavaliada pelo menos a cada cinco anos, estabelecerá: I - os percentuais de que trata o $\S 22^{\circ}$; II - os critérios de rateio dos recursos da União vinculados à saúde destinados aos Estados, ao Distrito Federal e aos Municípios, e dos Estados destinados a seus respectivos Municípios, objetivando a progressiva redução das disparidades regionais; III - as normas de fiscalização, avaliação e controle das despesas com saúde nas esferas federal, estadual, distrital e municipal; IV - as normas de cálculo do montante a ser aplicado pela União". BRASIL. Constituição da República Federativa do Brasil de 1988, cit.

${ }^{41}$ NUNES, António José Avelãs; SCAFF, Fernando Facury, op. cit., p. 85. 
Diante disso, concluímos que: (a) há uma segunda posição em relação à judicialização do direito prestacional à saúde; (b) essa segunda posição apresenta o direito prestacional à saúde como um direito subjetivo prima facie; (c) ao se adotar essa percepção, tende-se a deferir os pedidos que se baseiem na aplicação dos artigos $6^{\circ}$ e 196 da CF/88; e (d), no entanto, as razões da decisão trazem o elemento custo do direito, ainda que sempre como um argumento fraco, que ou é insuficiente ou reforça (legitima) a posição maximalista.

\title{
II. 0 impacto orçamentário das decisões judiciais
}

A importância de demonstrar a necessidade de os custos serem levados a sério pelo STF reside na preocupação com o impacto orçamentário gerado pelo deferimento de demandas judiciais que tenham como conteúdo o requerimento, junto ao Estado, de medicamento ou tratamento não previsto nas políticas públicas de saúde. Procuraremos demonstrar se o chamado efeito multiplicador pode se tornar um obstáculo à efetividade do direito prestacional à saúde no que tange ao impacto orçamentário, sendo fulcral que o custo do direito prestacional à saúde também seja ponderado na decisão, ainda que gere o deferimento.

A concessão de prestações sociais a determinados indivíduos tem reflexos orçamentários, conforme a ordem jurídico-constitucional brasileira. O Estado prevê uma determinada despesa em relação ao direito prestacional à saúde, estabelecendo quais medicamentos e tratamentos serão financiados. O Poder Judiciário, ao intervir, deferindo medicamentos ou tratamentos não previstos, causa um impacto no orçamento público.

Reforçamos nosso entendimento de que o fato de o direito prestacional à saúde ser realizado por meio da provisão de bens coletivos e de políticas públicas de saúde que são colocadas em prática para a coletividade ${ }^{42}$ não é, por si só, um obstáculo à justiciabilidade. Porém, a garantia de tais bens depende de gastos e programas orçamentários,

\begin{abstract}
por isso o fornecedor de bens coletivos necessita de recursos materiais e institucionais (recursos de poder) tanto para criá-los quanto para evitar o perigo constante do carona (o free rider ou predador) que, valendo-se das características do bem público/coletivo, tenta beneficiar-se dele sem pagar a respectiva "conta" ${ }^{34}$.
\end{abstract}

Portanto, a preocupação com o efeito multiplicador não representa uma violação à dignidade da pessoa humana ou ao direito de ação (artigo $5^{\circ}$, inciso XXXV, $\mathrm{CF} / 88$ ); pelo contrário, verificar o impacto orçamentário reafirma nossa posição de que a solução do dilema justiticiabilidade versus orçamento é resolvido pelo estabelecimento de critérios para o controle das políticas públicas de saúde pelo Poder

\footnotetext{
${ }^{42}$ LOPES, José Reinaldo de Lima. Os Tribunais e os direitos sociais no Brasil - saúde e educação: um estudo de caso revisitado, cit., p. 236.

${ }^{43}$ Id. loc., cit.
} 
Judiciário. Há evidências de que, somente no Estado de São Paulo, a taxa de sucesso do demandante em casos envolvendo pedido de medicamentos seja de cerca de $85 \%{ }^{44}$. Questões relativas ao orçamento público, como escassez de recursos e a não previsão de despesas, não são consideradas nessas demandas ${ }^{45}$. Na prática, o pedido de um tratamento médico, qualquer que seja, está coberto pelo artigo $196 \mathrm{da} \mathrm{CF} / 88$, em que pese os esforços da doutrina e da ordem jurídica brasileira em demonstrar o contrário.

A prática dos pedidos de medicamentos não constantes em listas e que conduzem ao efeito multiplicador é tão presente, que a própria mídia brasileira tratou de explicar "os dez passos para o deferimento judicial de um medicamento de alto custo" ${ }^{46}$. No campo da saúde pública, inclusive, o fenômeno é objeto de estudo e é chamado de "remédio com força de lei" 47.

Se analisarmos, sob a ótica orçamentária, o deferimento de uma ação que tenha como conteúdo o pedido de um medicamento ou tratamento não previsto nas políticas públicas de saúde, este, por si só, dificilmente gerará um impacto orçamentário preocupante; principalmente, considerando-se o total disponibilizado para os serviços e ações de saúde na LOA da União.

A judicialização da saúde, entre 2007 e 2011, aponta um crescimento de $1.237 \%$ nos gastos da União com ações judiciais para o fornecimento de medicamentos. Até outubro de 2011, as despesas com essas ações judiciais tinham alcançado a marca de R\$339,7 milhões ${ }^{48}$ : “Como comparação, os R\$ 339,7 milhões são 2,6 vezes o investimento anual do Ministério [da Saúde] na incorporação, no SUS, do medicamento trastuzumabe - utilizado contra o câncer de mama"49.

De um lado, percebemos que há um crescimento significativo no número de demandas judiciais requerendo medicamentos e, consequentemente, um aumento

${ }^{44}$ WANG, Daniel; PIRES, Natália; OLIVEIRA, Vanessa Elias de; TERRAZAS, Fernanda. Os impactos da judicialização saúde no orçamento público da saúde: o caso do Município de São Paulo. Disponível em: <http:// abresbrasil.org.br/sites/default/files/trabalho_23.pdf>. Acesso em: 20 jan. 2014.

${ }^{45}$ Id. Ibid.

${ }^{46}$ RECORRER à justiça acelera o recebimento de medicamentos de alto custo. Disponível em: <http://noticias.r7.com/saude/noticias/recorrer-a-justica-acelera-recebimento-de-remedios-de-alto-custo-20120401. html>. Acesso em: 20 jan. 2014.

${ }^{47}$ MACEDO, Eloisa Israel de; LOPES, Luciane Cruz; BARBERATO-FILHO, Silvio. Análise técnica para a tomada de decisão do fornecimento de medicamentos pela via judicial. Revista Saúde Pública, São Paulo, v. 4, n. 45, p. 710, 2011. Disponível em: <http://www.scielo.br/scielo.php?script=sci_arttext\&pid=S0034-89102011005000044>. http://dx.doi.org/10.1590/S0034-89102011005000044. A institucionalização da despesa pública com o custeio do medicamento atendido via judicial tornou-se tão evidente, que há a Proposta de Emenda Constitucional n. 264/2013, que acrescentaria o parágrafo $7^{\circ}$ ao artigo 198 da $\mathrm{CF} / 88$, com a seguinte redação: “ $\S 7^{\circ}$. No caso de ocorrer ordem judicial para a realização de despesas de compra de medicamentos, despesas médicas hospitalares e de internação a serem custeados pelos municípios, a União obrigatoriamente participará com $75 \%$ (setenta e cinco por cento) do valor e o Estado de origem da ação ou Distrito Federal, participará com 25\% (vinte e cinco por cento) do custeio". BRASIL. Câmara dos Deputados. Proposta de Emenda Constitucional $n$. 264/2013. Disponível em: <http://www.camara.gov.br/proposicoesWeb/prop_mostrarintegra?codteor=10907 32\&filename=PEC+264/2013> Acesso em: 20 jan. 14.

${ }^{48}$ SUS tem despesa recorde com ações judiciais. Disponível em: <http://www1.folha.uol.com.br/ cotidiano/1199942-sus-tem-despesa-recorde-com-acoes-judiciais.shtml> Acesso em: 20 jan. 2014.

${ }^{49}$ SUS tem despesa recorde com ações judiciais, cit. 
nas despesas públicas com essa espécie de demanda. De outro lado, não encontramos nenhuma consideração efetiva em relação à escassez de recursos e ao orçamento público diante da escalada de ações judiciais que têm como objeto o fornecimento de medicamento não previsto na Relação Nacional de Medicamentos Essenciais (Rename). De fato, o cenário é de potencialização ou efetivação do efeito multiplicador. Em números, na atualidade, há anualmente cerca de 40 mil ações judiciais no Brasil cujo objeto é o fornecimento de medicamentos e em que há quase sempre uma preponderância do direito à saúde sem nenhuma restrição aos artigos $6^{\circ}$ e 196 da CF/88, "gerando cargas administrativas crescentes e custos significativos ao já saturado sistema de saúde pública brasileiro" ${ }^{50}$.

Nesse sentido, o crescimento de demandas judiciais voltadas ao fornecimento de um medicamento ou tratamento a partir de uma percepção "maximalista" do direito fundamental à saúde pode comprometer a aplicação de recursos para outras áreas da saúde. Além disso, essa postura do Poder Judiciário favorece a estratégia da indústria farmacêutica de criar mercado para seus novos produtos, que muitas vezes ocorre em função do desconhecimento dos prescritores da Rename - ou da não adoção de critérios de racionalização no uso de medicamentos ${ }^{51}$. A Rename diminui a margem de apreciação do julgador, mas não impede - desde que com base em critérios técnico-científicos - a adoção de medicamentos não previstos nela.

Não pretendemos, com isso, restringir o significado dogmático-constitucional do artigo 196 da CF/88. Inversamente, defendemos que sua delimitação passe, assim como todos os direitos em função de seus custos, pela conjugação de questões orçamentárias. Como podemos comprovar no primeiro capítulo, trata-se de corolário da teoria dos direitos fundamentais.

Do que examinamos, concluímos que: (a) as ações judiciais que demandam medicamentos/tratamentos têm um impacto significativo no orçamento público; (b) o crescente número de demandas cujo objeto é o pedido de medicamento/tratamento

\footnotetext{
50 "Gerando crescimento dos encargos administrativos e custos significativos para o sistema público de saúde brasileiro cuja situação é tensa". FERRAZ, Octávio Luiz Motta. Harming the poor through social rights litigation: lessons from Brazil. Texas Law Review, v. 89, p. 1652, jun. 2011.

${ }^{51} \mathrm{CHIEFFI}$, Ana Luiza; BARATA, Rita de Cássia Barradas. Ações judiciais: estratégia da indústria farmacêutica para a introdução de novos medicamentos. Revista Saúde Pública, São Paulo, v. 3, n. 44, p. 423, 2010. Disponível em: <http://www.revistas.usp.br/rsp/article/view/32787>. http://dx.doi.org/10.1590/S003489102010000300005 . "Por outro lado, para os casos de medicações não disponíveis nas opções gratuitas ou subsidiadas mencionadas, que conduzam a uma demanda judicial, seria conveniente sugerir ao poder judiciário as informações mínimas que devem constar nos processos, a fim de subsidiar a decisão dessa instância: o motivo pelo qual se prescreve a medicação baseada no quadro clínico do paciente e sua doença de base e comorbidades associadas; descrição da Classificação Internacional de Doenças e Problemas Relacionados à Saúde (CID); relato de eventuais falhas terapêuticas anteriores; detalhar a evolução clínica para que a medicação seja dispensada criteriosamente; na existência dos dados de parâmetro laboratoriais, estes devem estar anexados ao processo; e ainda, na impossibilidade de fornecer as duas últimas informações, ao menos justificar com base em adequada(s) evidência(s) científica(s) a solicitação afim de respaldar a opção pleiteada". GALATO, Dayani; NESI, Humberto; ROSSO, José Antônio; OLIVEIRA, Rita de Cássia Schmitz Mendes; TRAUTHMAN, Silvana Cristina; LUNARDI, Tânia; SCHUELTER-TREVISOL, Fabiana. Judicialização de medicamento no Brasil: um processo que deve ser racionalizado. Revista Saúde Pública, São Paulo, v. 2, n. 46, p. 390-391, abr. 2012. Disponível em: <http://www.scielo.br/pdf/rsp/v46n2/3902.pdf>. http://dx.doi.org/10.1590/S0034-89102012000200023.
} 
não previsto na política pública de saúde via Poder Judiciário aponta para a ocorrência do efeito multiplicador; e (c) é preciso ressignificar o direito prestacional à saúde a partir de condições e critérios constitucionais para que a multiplicação de ações não inviabilize a efetividade do mínimo vital do direito à saúde.

\section{Considerações finais}

A crescente judicialização do direito prestacional à saúde e, de uma forma geral, dos direitos sociais prestacionais tem despertado o debate sobre os limites da intervenção do Poder Judiciário e sobre a fundamentação das decisões desse Poder. À medida que se espera um papel mais responsivo do Judiciário, maiores se tornam as necessidades de aprimoramento das decisões sob a ótica argumentativa.

Essas questões fogem das funções tradicionais do Poder Judiciário. Intervir e decidir em matérias das políticas públicas sociais que determinam a vida não se insere dentro das funções tradicionais, por certo. A intervenção do Poder Judiciário, estritamente em matéria de direitos prestacionais, tende a destacar as limitações financeiras das prestações disponibilizadas pelo Estado. Nesse sentido, a opção pela intervenção do Poder Judiciário, pela atipicidade da atividade, pode facilmente se tornar uma forma de ativismo judicial ou, como diz Pisarello, "populismo judicial".

No centro desse fenômeno, as decisões do STF tornam-se a base para a atuação em primeira e segunda instâncias, sendo largamente reproduzidas. Por isso, investigamos - por meio da análise de decisões do STF, pesquisados os termos "políticas públicas" e "saúde" - se o custo do direito prestacional à saúde é utilizado como um argumento forte nessas decisões.

O que podemos perceber é que o STF, na maioria absoluta de seus julgados, adota uma posição que chamamos de "maximalista". Esta utiliza a dicção dos artigos $6^{\circ} \mathrm{e}$ 196 da CF/88 e constrói uma decisão que justifique o deferimento prima facie do direito prestacional à saúde. Ela se apresenta em duas variáveis: a primeira é a maximalista sem ponderação de custos (que ignora o elemento custo do direito, ou o desconsidera) e a segunda é a maximalista com ponderação de custos (que pondera o custo, mas este nunca aparece como um argumento forte para negar o pedido). Nessa linha de raciocínio, o custo do direito é tido pelo STF como um aspecto menor (argumento fraco) ou como algo repugnante - ou até imoral - para seja levado a sério em suas decisões.

Apesar disso, percebemos que há um avanço positivo nas posições adotadas pelos ministros do STF, no sentido de superar uma lacuna entre essas posições e a teoria dos direitos fundamentais que não ignora os custos dos direitos fundamentais. Lembrando que não considerar custos pode significar a abertura de duas portas SUS brasileiro, por meio do efeito multiplicador delas: a porta daqueles que utilizam os procedimentos administrativos previstos e a porta daqueles que têm acesso aos procedimentos judiciais e que os conhecem. Não há como ampliar o orçamento por simples alvedrio do Poder Judiciário. 


\section{Referências}

ALEXY, Robert. Teoría de los derechos fundamentales. Madrid: Centro de Estudíos Politicos y Constitucionales, 2008.

AMARAL, Gustavo. Direito, escassez \& escolha: em busca de critérios jurídicos para lidar com a escassez de recursos e as decisões trágicas. Rio de Janeiro: Renovar, 2001.

; MELO, Daniele. Há direitos acima dos orçamentos? In: SARLET, Ingo; TIMM, Luciano Benetti (Coords.). Direitos fundamentais: orçamento e "reserva do possível". Porto Alegre: Livr. do Advogado, 2013.

ARANGO, Rodolfo. El concepto de derechos sociales fundamentales. Bogotá: Legis, 2012.

El derecho a la salud en la jurisprudencia constitucional colombiana. Revista da Defensoria Pública do Estado de São Paulo, ano 1, n. 1, jul./dez. 2008.

Los derechos sociales en iberoamérica: estado de la cuestión y perspectiva de futuro. Cuadernos Eletrónicos de Derechos Humanos y Democracia, n. 5, fev. 2010. Disponível em: $<$ http://www.portalfio.org/inicio/archivos/cuadernos_electronicos/numero_5/1_\%20Los\%20 derechos\%20sociales\%20en\%20Iberoam\%C3\%A9rica.pdf>. Acesso em: 08 dez. 2013.

ÁVILA, Humberto Bergmann. Teoria dos princípios: da definição à aplicação dos princípios jurídicos. São Paulo: Malheiros Ed., 2012.

BALEEIRO, Aliomar. Uma introdução à ciência das finanças. Rio de Janeiro: Forense, 1955. v. 2.

BARROS, Marcus Aurélio de Freitas. Controle jurisdicional de políticas públicas: parâmetros objetivos e tutela coletiva. Porto Alegre: Sergio Antonio Fabris, 2008.

BARROSO, Luís Roberto. Da falta de efetividade à judicialização excessiva: direito à saúde, fornecimento gratuito de medicamentos e parâmetros para a atuação judicial. Disponível em: $<$ http://www.lrbarroso.com.br/pt/noticias/medicamentos.pdf $>$. Acesso em 08 nov. 2008.

CAMPANTE, Rubens Goyatá. Direitos sociais e justiça. In: AVRITZER, Leonardo (Orgs.). Dimensões políticas da justiça. Rio de Janeiro: Civilização Brasileira, 2013.

CANELA JUNIOR, Osvaldo. Controle judicial de políticas públicas. São Paulo: Saraiva, 2011.

CHIEFFI, Ana Luiza; BARATA, Rita de Cássia Barradas. Ações judiciais: estratégia da indústria farmacêutica para a introdução de novos medicamentos. Revista Saúde Pública, São Paulo, v. 3, n. 44, 2010. Disponível em: <http://www.revistas.usp.br/rsp/article/view/32787>. http://dx.doi.org/10.1590/S0034-89102010000300005.

CORTI, Horacio G. Derechos fundamentales y presupuesto público: una renovada relación en el marco del neoconstitucionalismo periférico. In: CONTI, José Mauricio; SCAFF, Fernando Facury (Coord.). Orçamentos públicos e direito financeiro. São Paulo: Ed. Revista dos Tribunais, 2011. 
COUTO, Cláudio Gonçalves. Constituição, competição e políticas públicas. Lua Nova, São Paulo, n. 65, p. 95-135, 2005. Disponível em: <http://www.scielo.br/pdf/ln/n65/a05n65.pdf >. http://dx.doi.org/10.1590/S0102-64452005000200005.

DIAS, Maria Tereza Fonseca; ESTEVES, Júlio César dos Santos; FORTINI, Cristiana (Orgs.). Políticas públicas: possibilidades e limites. Belo Horizonte: Fórum, 2008.

FERRAZ, Octávio Luiz Motta. Harming the poor through social rights litigation: lessons from Brazil. Texas Law Review, v. 89, jun. 2011.

FIGUEIREDO, Marcelo. O controle de políticas públicas pelo Poder Judiciário no Brasil: uma visão geral. Revista Interesse Público, v. 44, p. 27-66, jul./ago. 2007. Disponível em: $<$ http://revistas.pucsp.br/index.php/red/article/viewFile/736/509>. Acesso em: 17 set. 2015.

FRIEDMAN, Milton. Capitalism and freedom. Chicago: Chicago Press, 2002.

GALATO, Dayani; NESI, Humberto; ROSSO, José Antônio; OLIVEIRA, Rita de Cássia Schmitz Mendes; TRAUTHMAN, Silvana Cristina; LUNARDI, Tânia; SCHUELTER-TREVISOL, Fabiana. Judicialização de medicamento no Brasil: um processo que deve ser racionalizado. Revista Saúde Pública, São Paulo, v. 2, n. 46, p. 390-391, abr. 2012. Disponível em: <http://www.scielo.br/pdf/rsp/v46n2/3902.pdf>. http://dx.doi.org/10.1590/S0034-89102012000200023.

GRAU, Eros Roberto. Ensaio sobre a interpretação/aplicação do direito. São Paulo: Malheiros Ed., 2006.

. O discurso neoliberal e a teoria da regulação. In: CAMARGO, Ricardo Antônio Lucas (Coord.). Desenvolvimento econômico e intervenção do Estado na Ordem Constitucional: estudos jurídicos em homenagem ao Professor Washington Peluso Albino de Souza. Porto Alegre: Sergio Antonio Fabris, 1995.

. A Ordem Econômica na Constituição de 1988. São Paulo: Malheiros Ed., 2007.

GRINOVER, Ada Pellegrini; WATANABE, Kazuo (Coords.). O controle jurisdicional de políticas públicas. Rio de Janeiro: Forense, 2011.

GUASTINI, Riccardo. La constitucionalización del ordenamiento jurídico: el caso italiano. In: CARBONELL, Miguel. Neoconstitucionalismo(s). Madrid: Trotta, 2005.

GUASTINI, Riccardo. Interpretare e argomentare. Milano: Giuffrè, 2011.

HAYEK, Friedrich. O caminho para a servidão. Lisboa: Edições 70, 2009.

HESSE, Konrad. Elementos de direito constitucional da República Federal da Alemanha (Grundzüge des Verfassungsrechts der Bundesrepublik Deutschland). Porto Alegre: Sergio Antonio Fabris, 1998.

HOLMES, Stephen; SUNSTEIN, Cass R. The cost of rights: why liberty depends on taxes. New York: Norton, 2000. 
LOPES, José Reinaldo de Lima. Direitos sociais: teoria e prática. São Paulo: Método, 2006.

Os Tribunais e os direitos sociais no Brasil - saúde e educação: um estudo de caso revisitado. In: LOPES, José Reinaldo de Lima. Direitos sociais: teoria e prática. São Paulo: Método, 2006.

LOUREIRO, João Carlos. Direito à (proteção da) saúde. Revista da Defensoria Pública de São Paulo, ano 1, n. 1, p 35-73, jul./dez, 2008.

MACEDO, Eloisa Israel de; LOPES, Luciane Cruz; BARBERATO-FILHO, Silvio. Análise técnica para a tomada de decisão do fornecimento de medicamentos pela via judicial. Revista Saúde Pública, São Paulo, v. 4, n. 45, p. 706-713, 2011. Disponível em: $<$ http://www.scielo.br/scielo.php?script=sci_arttext\&pid=S0034-89102011005000044>. http://dx.doi.org/10.1590/S0034-89102011005000044.

MAURICIO JUNIOR, Alceu. A revisão judicial das escolhas orçamentárias: a intervenção judicial em políticas públicas Belo Horizonte: Fórum, 2009.

MENDES, Conrado Hübner. Constitutional courts and deliberative democracy. Oxford: Oxford, 2013.

MENDONÇA, Eduardo Bastos Furtado. A constitucionalização das finanças públicas no Brasil: devido processo orçamentário e democracia. Rio de Janeiro: Renovar, 2008.

MOREIRA NETO, Diogo de Figueiredo. Poder, Direito e Estado: o direito administrativo em tempos de globalização. Belo Horizonte: Fórum, 2011.

Quatro paradigmas do direito administrativo pós-moderno: legitimidade; finalidade; eficiência; resultados. Belo Horizonte: Fórum, 2008.

NABAIS, José Casalta. O dever fundamental de pagar impostos: contributo para a compreensão constitucional do estado fiscal contemporâneo. Lisboa: Almedina, 1998.

A face oculta dos direitos fundamentais: os deveres e os custos dos Direitos. In: NABAIS, José Casalta. Por uma liberdade com responsabilidade: estudos sobre direitos e deveres fundamentais. Coimbra: Coimbra Ed., 2007.

Por uma liberdade com responsabilidade: estudos sobre direitos e deveres fundamentais. Coimbra: Coimbra Ed., 2007.

NUNES, António José Avelãs; SCAFF, Fernando Facury. Os Tribunais e o direito à saúde. Porto Alegre: Livraria do Advogado, 2011.

PENNA, Saulo Versiani. O controle e implementação processual de políticas públicas no Brasil. Belo Horizonte: Fórum, 2011.

PIOVESAN, Flávia. Direitos humanos e direito constitucional internacional. São Paulo: Saraiva, 2013. 
RECORRER à justiça acelera o recebimento de medicamentos de alto custo. Disponível em: $<$ http://noticias.r7.com/saude/noticias/recorrer-a-justica-acelera-recebimento-de-remediosde-alto-custo-20120401.html>. Acesso em: 20 jan. 2014.

SARLET, Ingo. A eficácia dos direitos fundamentais. Porto Alegre: Livr. do Advogado, 2010.

; FIGUEIREDO, Mariana Filchtiner. O direito fundamental à proteção e promoção da saúde no Brasil: principais aspectos e problemas. Disponível em: <http://www. editorajuspodivm.com.br/i/f/ingo.pdf >. Acesso em: 02 dez. 2013.

SHULTZ, Jim. Promises to keep: using public budgets as a tool to advance economic, social and cultural rights. México: Ford Fundation and FUNDAR - Center for Analisys and Research, 2002. Disponível em: <http://www.internationalbudget.org/themes/ESC/FullReport.pdf>. Acesso em: 02 fev. 2014.

SUS tem despesa recorde com ações judiciais. Disponível em: <http://www1.folha.uol.com.br/ cotidiano/1199942-sus-tem-despesa-recorde-com-acoes-judiciais.shtml> Acesso em:20 jan. 2014.

TORRES, Ricardo Lobo. As relações entre receita e despesa na Constituição. In: COUTINHO, Jacinto Nelson de Miranda; MORAIS, José Luis Bolzan; STRECK, Lenio Luiz. Estudos constitucionais. Rio de Janeiro: Renovar, 2007.

. Tratado de direito tributário e financeiro (o orçamento na Constituição). Rio de Janeiro: Renovar, 2000. v. 5.

TRINDADE, Antônio Augusto Cançado. A proteção internacional dos direitos humanos: fundamentos jurídicos e instrumentos básicos. São Paulo: Saraiva, 1991.

Tratado de direito internacional dos direitos humanos. Porto Alegre: Sérgio Fabris, 1997.

VALLE, Vanice Regina Lírio do. Políticas públicas, direitos fundamentais e controle judicial. Belo Horizonte: Fórum, 2009.

WANG, Daniel; PIRES, Natália; OLIVEIRA, Vanessa Elias de; TERRAZAS, Fernanda. Os impactos da judicialização saúde no orçamento público da saúde: o caso do Município de São Paulo. Disponível em: <http://abresbrasil.org.br/sites/default/files/trabalho_23.pdf > . Acesso em: 20 jan. 2014.

Hector Cury Soares - Doutor em Direito Público pela Universidade Federal do Rio Grande do Sul e pela Universidade de Coimbra (Portugal); mestre em Direito Público pela Universidade do Vale do Rio dos Sinos. Professor Adjunto da Universidade Federal do Pampa (Santana do Livramento); coordenador do Grupo de Pesquisa "Direito, Estado e Movimentos Sociais". Porto Alegre/RS, Brasil. E-mail: hectorcury@gmail.com. 